\title{
PELESTARIAN WARISAN BUDAYA KOTA (URBAN HERITAGE) MELALUI PENDEKATAN HERITAGE URBAN LANDSCAPE (HUL) DAN CULTURAL HERITAGE INTEGRATED MANAGEMENT PLANS (CHIMP)
}

\section{PRESERVATION OF URBAN HERITAGE \\ USING HERITAGE URBAN LANDSCAPE (HUL) AND CULTURAL HERITAGE INTEGRATED MANAGEMENT PLANS (CHIMP) APPROACHES}

\author{
Brahmantara \\ Balai Konservasi Borobudur \\ bramantarayk@gmail.com
}

\begin{abstract}
ABSTRAK
Pelestarian warisan budaya kota (urban heritage) saat ini mengalami tantangan yang cukup besar. Laju pembangunan menjadi ancaman dalam menggeser nilai nilai budaya itu sendiri. Bagaimana mendesain sinergitas antara warisan yang bersifat fisik dan nofisik melalui pendekatan Heritage Urban Landscape (HUL) dan Cultural Heritage Integrated Management Plans (CHIMP)? Apakah kedua metode tersebut sesuai untuk diterapkan? Lantas, bagaimana kedua metode tersebut bekerja? Dalam pengelolaan dan pelestarian warisan budaya perkotaan (urban heritage), ada dua pendekatan yang dilakukan. Pertama adalah pendekatan Heritage Urban Landscape (HUL), pendekatan ini dilakukan dengan metode melihat warisan budaya kota sebagai aset sosial, ekonomi dan budaya untuk pengembangan kota dan bergerak diluar pelestarian fisik lingkungan, dan berfokus kepada lingkungan manusia beserta lingkungannya baik yang bersifat bendawi maupun tak bendawi. Metode yang kedua adalah pelestarian dengan pendekatan Rencana Manajemen Terpadu Warisan Budaya (Cultural Heritage Integrated Management Plans / CHIMP). CHIMP adalah instrumen inovatif yang secara efektif mengelola perlindungan dan pengembangan daerah perkotaan bersejarah secara berkelanjutan menuju warisan budaya kota yang menarik, kompetitif dan multifungsi. Instrumen ini menyeimbangkan dan mengkoordinasikan antara kebutuhan akan warisan budaya dengan kebutuhan dari "pengguna" (masyarakat) dan stakeholder terkait yang bertanggung jawab terhadap kelangsungan dari warisan budaya kota tersebut. Metode pendekatan tersebut baik HUL maupun CHIMP sesuai untuk diterapkan dalam pelestarian warisan budaya kota. Kedua metode tersebut mampu menghubungkan dan menyeimbangkan antara pembangunan sosial- ekonomi yang berkelanjutan dengan perlindungan warisan budaya dan identitas yang dimiliki. HUL lebih banyak bergerak diluar pelestarian fisik lingkungannya, sedangkan CHMIP bergerak disemua aspek pelestarian. Perbedaan bukan merupakan suatu kelebihan dan kekurangan, namun merupakan dua pendekatan yang sebenarnya saling melengkapi. Identifikasi karakteristik yang dimiliki ini menjadi penentuan awal apakah metode pendekatan dengan HUL atau CHIMP. Karakteristik kota yang didominasi oleh karakter dan nilai budaya yang bersifat fisik lebih cocok menggunakan pendekatan CHIMP dan sebaliknya kota yang mempunyai lebih banyak karakter nilai budaya non fisik akan lebih sesuai menggunakan pendekatan HUL.
\end{abstract}

Kata Kunci: Urban Heritage, Heritage Urban Landscape (HUL); Cultural Heritage Integrated Management Plans (CHIMP)

\section{ABSTRACT}

Today the preservation of urban heritage has been faced with big challenges. One of them is the development drive that might replace cultural values. How to design a synergy between tangible and intangible heritage through Heritage Urban Landscape (HUL) and Cultural Heritage Integrated Management Plans (CHIMP) approcahes? Are those two approaches suitable? Then, how they can be implemented? In the management and preservation of urban heritage, there are two approaches that can be used. The first is Heritage Urban Landscape (HUL), performed by using a method to understand urban heritage as social, economic, and cultural assets within urban development, while being construed outside physical conservation, and focusing on the human 
environment both in tangible and intagible aspects. The second is Cultural Heritage Integrated Management Plans (CHIMP). CHIMP is an innovative instrument in effectively managing the protection and development of historical urban area, which is sustainable for attractiveness, competitiveness, and multifunctionality. This instrument balances and coordinates the needs from "user" (community) and related stakeholders, which are responsible for the management of urban heritage. The approaches, both HUL and CHIMP, are suitable to be implemented in the preservation of urban heritage. Both methodologies could connect and balance sustainable socioeconomic development an protection cultural heritage and identity. HUL operates outside physical area conservation, while CHMIP covers all aspects of preservation. This difference is not to say that one is better than other, but that both completes each other. Character identification would be initial step to determine which approach to be used. CHIMP is suitable for urban area that is dominated by tangible characters and heritage, while on the other hand, HUL is compatible for urban landscape that is abundant in its intangible heritage.

Keywords: Urban Heritage; Heritage Urban Landscape (HUL); Cultural Heritage Integrated Management Plans (CHIMP)

\section{PENDAHULUAN}

Seperti halnya perkembangan pengelolaan lanskap pada warisan budaya perkotaan yang ada di Eropa, di Indonesia pun mengalami hal yang demikian. Ketidakseimbangan antara pembangunan ekonomi dan pelestarian warisan budaya kota mengakibatkan kemandegan (stagnasi) salah satu dari kedua unsur tersebut. kondisi yang sering terjadi adalah pembangunan ekonomi yang tidak terintegrasi dengan konsep pelestarian yang kemudian mengakibatkan hilangnya nilai-nilai warisan budaya dan identitas yang dimiliki oleh kota tersebut.

Warisan budaya perkotaan merupakan sumber daya kunci dalam meningkatkan liveability dari daerah perkotaan. Kondisi ini menumbuhkan pembangunan ekonomi dan kohesi sosial dalam lingkungan global yang berubah. Diperlukan tingkat kesadaran untuk mencari skema yang inovatif. Keterlibatan berbagai sektor publik, swasta dan sipil dalam pengelolaan warisan budaya perkotaan merupakan kondisi yang diperlukan untuk mewujudkan kelestarian dari warisan budaya perkotaan tersebut. "Warisan berwujud (tangible) dan tak berwujud (intangible) merupakan sumber kohesi sosial, faktor keragaman dan driver kreativitas, inovasi dan regenerasi perkotaan - kita harus berbuat lebih banyak untuk memanfaatkan kekuatan ini" (Bokova dalam Banderin, 2012). Satu hal mendasar yang penting dalam memahami dan mengelola warisan budaya perkotaan adalah pengakuan bahwa kota bersejarah tidak hanya sebuah monumen yang statis ataupun sekumpulan bangunan-bangunan bersejarah saja, namun kekuatan dinamis dalam aspek ekonomi, sosial dan budaya merupakan unsur yang membentuk dan menjaganya.

Pelestarian warisan budaya kota (urban heritage) menjadi isu yang berkembang cukup pesat. Jaringan kemitraan antara kota bersejarah menjadi satu wadah yang penting dalam mengembangkan strategi manajemen pengelolaan terpadu dan inovatif dalam pelestarian warisan budaya kota. Tujuan dibentuknya jaringan kemitraan ini cenderung kepada bagaimana memfasilitasi keseimbangan yang tepat antara pelestarian nilai yang ada pada warisan budaya kota dengan pembangunan ekonomi, sosial dan budaya. Keseimbangan ini diharapkan mampu memberikan daya tarik yang pada akhirnya akan menumbuhkan kepedulian terhadap kelestarian khususnya masyarakat lokal yang menjadi bagian penting dari nilai penting yang ada pada kota bersejarah tersebut. Strategi tersebut dilakukan melalui penekanan pada pengelolaan yang tidak sesuai dengan kepentingan pemanfaatan, justru hal yang menjadi menarik untuk dikembangkan adalah bagaimana potensi/aset yang dimiliki oleh sebuah warisan budaya kota (urban heritage) dapat dimanfaatkan untuk kegiatan ekonomi, sosial dan budaya ("heritage as opportunity") 
(Regensburg, 2011: 5). Tantangan utama dalam warisan budaya kota (urban heritage) adalah bagaimana mencocokkan warisan nilai bagi dari segi fisik dan non-fisik atau bendawi (tangible) dan tak benda (intangible) yang dimiliki oleh kota bersejarah tersebut dengan kepentingan yang dimiliki oleh masyarakat, dimana tuntutan yang diharapkan dari berbagai masyarakat mempunyai karakteristik yang berbeda-beda. Bahwa pengelolaan yang dilakukan dengan pendekatan yang tepat perlu dilakukan agar pemanfaatan warisan budaya tersebut dapat bersentuhan langsung kepada masyarakat, berperan dalam menjaga kualitas hidup baik masyarakat maupun pengunjungnya, serta menjaga nilai dan identitas yang dimiliki untuk generasi sekarang dan generasi yang akan datang.

\section{Rumusan Permasalahan}

Permasalahan dalam pelestarian warisan budaya kota adalah bagaimana menghubungkan dan menyeimbangkan antara pembangunan sosial- ekonomi yang berkelanjutan dengan perlindungan warisan budaya dan identitas yang dimiliki. melalui pendekatan yang sesuai dengan tujuan warisan pelestarian itu sendiri. Sesuai dengan topik dalam kajian ini, maka rumusan masalah yang menjadi titik tolak kajian literatur ini adalah apakah metode pendekatan dengan Heritage Urban Landscape (HUL) dan Cultural Heritage Integrated Management Plans (CHIMP) ini sesuai untuk perlindungan warisan budaya perkotaan? Dan bagaimana cara kerja kedua metode tersebut?

\section{Metode Pendekatan}

Metode pendekatan dalam pengelolaan dan pelestarian warisan budaya kota tidak lepas dari tiga aspek utama, yaitu : pembangunan sosial-ekonomi, perlindungan warisan budaya dan identitas yang dimiliki oleh kota tersebut. Adapun metode pendekatan yang dapat digunakan dalam pelestarian warisan budaya kota ini adalah:

\section{a Pendekatan Heritage Urban Landscape (HUL)}

Pendekatan ini dilakukan secara holistik, mengintegrasikan tujuan konservasi warisan budaya kota ini dengan pembangunan ekonomi dan sosial. Metode ini melihat warisan budaya kota sebagai aset sosial, ekonomi dan budaya untuk pengembangan kota. Pendekatan ini bergerak diluar pelestarian fisik lingkungan, dan berfokus kepada lingkungan manusia beserta lingkungannya baik yang bersifat bendawi maupun tak bendawi.

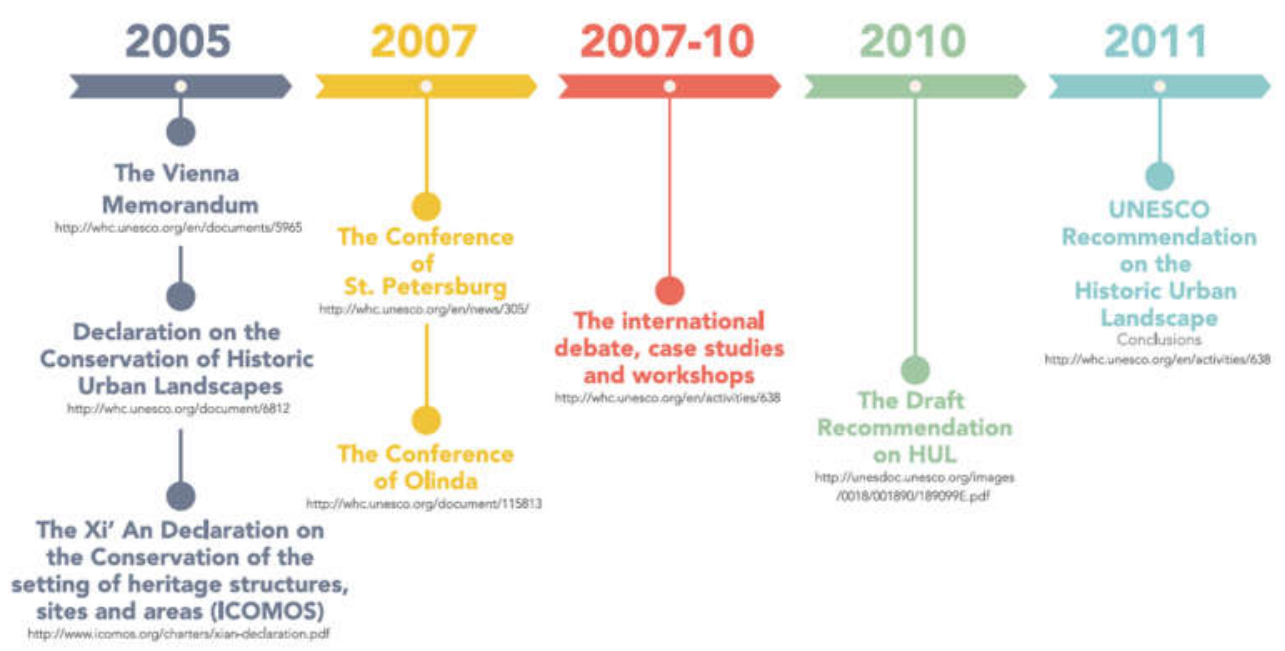

Gambar 1. Timeline pengembangan konsep HUL (Sumber: UNESCO, 2016) 
Pendekatan HUL sendiri awal dicetuskan pertama pada tahun 2005 melalui The Vienna Memorandum, kemudian mengalami pengembangan pada tahun 2007 sampai perkembangan terakhir pada tahun 2011 melalui dokumen Rekomendasi UNESCO dalam HUL (UNESCO, 2016). Secara terperinci, perkembangan tersebut dapat dilihat sebagai berikut:

Metode ini berusaha meningkatkan keberlanjutan perencanaan pengembangan kota dengan tetap memperhatikan lingkungan binaan, warisan budaya tak benda, keragaman budaya dan faktor sosial- ekonomi bersama-sama dengan niai-nilai yang tumbuh dalam masyarakat. Sebagaimana rekomendasi yang dijelaskan dalam Hul Guide Book bahwa keberhasilan dalam pendekatan ini mencakup serangkaian alat interdisipliner dan inovatif yang diorganisir dalam empat komponen, yaitu: community engagement (keterlibatan masyarakat), knowledge and planning tools (perencanaan dan ilmu pengetahuan), regulatory systems (sistem peraturan) dan financial (pembiayaan) (UNESCO, 2016).

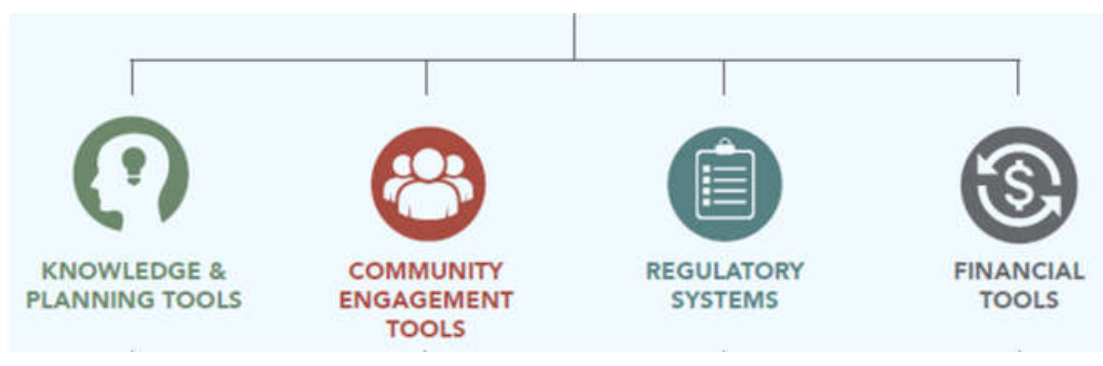

Gambar 2. Empat Komponen dalam Pendekatan HUL (Sumber: UNESCO, 2016)

Pendekatan HUL dalam pelestarian warisan budaya kota ini mempunyai tujuan untuk:

1. Melestarikan kualitas lingkungan manusia;

2. Meningkatkan penggunaan ruang secara produktif dan berkelanjutan melalui karakter yang dinamis;

3. Mempromosikan keragaman sosial dan fungsional.

Pendekatan ini dapat menjelaskan bahwa prinsip-prinsip operasional akan memastikan bahwa model konservasi warisan budaya yang dilakukan akan memperhatikan nilai, tradisi lingkungan dalam berbagai konteks budaya yang berbeda. Pembangunan berkelanjutan dalam warisan budaya kota ditafsirkan melalui tiga dimensi berkelanjutan yaitu: sosial, ekonomi dan lingkungan. Proses ini juga melibatkan profesional dalam mempromosikan nilai-nilai warisan, yang peran dan kompetensinya harus ditingkatkan untuk terlibat penuh dalam proses perencanaan, transmisi pengetahuan tidak hanya dari nilai-nilai warisan tradisional tetapi juga berasal dari orangorang yang mempunyai perspektif lanskap dan dimensi ekonomi, ekologi, sosial dari pembangunan yang berkelanjutan (Negussie et al, 2014). Dalam implementasinya, pendekatan Heritage Urban Landscape (HUL) ini dilakukan melalui 7 proses rencana aksi, yaitu :

1. Melakukan penilaian penuh sumber daya alam, budaya dan manusia kota;

2. Menggunakan partisipatif konsultasi perencanaan dan pemangku kepentingan untuk memutuskan tujuan konservasi dan tindakan;

3. Menilai kerentanan warisan perkotaan tekanan dan dampak perubahan iklim sosio- 
ekonomi;

4. Mengintegrasikan nilai-nilai warisan perkotaan dan status kerentanan mereka ke dalam kerangka yang lebih luas dari pembangunan kota;

5. Memprioritaskan kebijakan dan tindakan untuk konservasi dan pembangunan, termasuk pelayanan yang baik;

6. Menetapkan sesuai (public-private) kemitraan dan kerangka kerja manajemen lokal;

7. Mengembangkan mekanisme untuk koordinasi berbagai kegiatan antar stakeholder yang mempunyai kepentingan yang berbeda-beda.

\section{b. Pendekatan Rencana Manajemen Terpadu Warisan Budaya (Cultural Heritage Integrated Management Plans /CHIMP)}

Pendekatan CHIMP adalah instrumen inovatif yang secara efektif mengelola perlindungan dan pengembangan daerah perkotaan bersejarah secara berkelanjutan menuju warisan budaya kota yang menarik, kompetitif dan multifungsi. Instrumen ini menyeimbangkan dan mengkoordinasikan antara kebutuhan akan warisan budaya dengan kebutuhan dari "pengguna" (masyarakat) dan stakeholder terkait yang bertanggung jawab terhadap kelangsungan dari warisan budaya kota tersebut. CHIMP menentukan dan menetapkan strategi, tujuan, tindakan dan struktur manajemen yang tepat untuk menyeimbangkan antara kebutuhan dan kepentingan dari berbagai komponen pengguna serta mewujudkan warisan budaya perkotaan tersebut sebagai aset pembangunan (Scheffler et al, 2010). Pendekatan CHIMP ini mempunyai tujuan, antara lain:

1. Menjaga nilai-nilai warisan budaya yang ada didalam urban heritage,

2. Mengembangkan dan memastikan terwujudnya warisan budaya kota yang menarik, kompetitif dan multifungsi;

3. Menyeimbangkan tuntutan dari berbagai kepentingan, baik kebutuhan akan warisan budaya, kebutuhan dari para "pengguna" dengan orientasi pengembangan kedepan melalui pendekatan manajemen yang terintegrasi;

4. Melibatkan dan mengkoordinasikan semua kepentingan publik dan swasta yang relevan; koordinasi kebijakan sektoral; konsep rencana, tindakan yang terarah;

5. Mengelola dan menyeimbangkan kegunaan/fungsi dan tujuan yang berbeda dari "pengguna" kota seperti ekonomi lokal, warga, wisatawan, konservator, pemilik properti, kontraktor dll.

Dalam prosesnya CHIMP membutuhkan dua pendekatan metodologis, yaitu:

1. Pendekatan terintegrasi

Pendekatan terpadu dalam pendekatan CHIMP ini berfungsi untuk menghubungkan, menyeimbangkan dan mengkoordinasikan kebutuhan warisan budaya tangible dengan dengan kebutuhan sosio-ekonomi dan ekologis dari (manifold) "pengguna" dari wilayah perkotaan bersejarah. Pendekatan terpadu ini selanjutnya digunakan sebagai kendaraan untuk mengarahkan kepentingan warisan budaya sebagai cross-sectional untuk pembangunan berkelanjutan. Dua karakteristik dalam pendekatan terpadu ini mengikuti persyaratan :

a) Komprehensif, lintas tematik dan lintas sektoral

Dalam perluasan dan implementasi CHIMP semua elemen kota dan lembaga harus terlibat secara memadai, CHIMP berfungsi untuk mengkoordinasikan kebijakan sektoral, konsep, rencana dan aksi.

b) Komunikatif dan partisipatif

Dalam proses ini semua elemen terutama semua aktor swasta yang terlibat harus diidentifikasi dan diaktifkan untuk mengambil bagian dan peran dalam perluasan 
dan implementasi CHIMP.

2. Sistem manajemen.

Dari segenap proses dan tahapan dalam pendekatan CHIMP ini mulai dari menyeimbangkan berbagai kepentingan, mengembankan langkah yang tepat dalam perlindungan warisan dan pengembangan pembangunan berkelanjutan menuntut suatu sistem manajemen yang secara efektif dan tepat mampu mengelola dan menangani tuntutan yang berbeda-beda. Berdasarkan hal tersebut setidaknya ada tiga karakteristik yang harus dipenuhi dalam sistem manajemen ini, yaitu:

a) Pendekatan proses

CHIMP menguraikan proses yang diperlukan, memperhitungkan kegiatan dan interaksinya menuju keseimbangan, koordinasi dan memenuhi tuntutan yang berbeda dari dan menuju daerah perkotaan bersejarah. Tuntutan, input yang tersedia dan output yang diperlukan (untuk dapat memenuhi tuntutan) harus diketahui dan proses harus terstruktur sesuai dengan output yang diinginkan.

b) Manajemen dan pendekatan kontrol

CHIMP mendefinisikan dan menggambarkan tindakan yang diperlukan dan (manajemen) struktur untuk dapat melaksanakan siklus Plan-Do-Check-Act

c) Pendekatan perbaikan secara terus menerus

CHIMP terus melakukan update dan menyesuaikan kebutuhan (sejauh yang diperlukan).

Pendekatan CHIMP ini dilakukan melalui empat tahapan siklus yang disebut sebagai "siklus hidup" (Scheffler et al, 2009). Empat tahapan siklus tersebut dapat dijelaskan melalui Gambar 3 sebagai berikut:

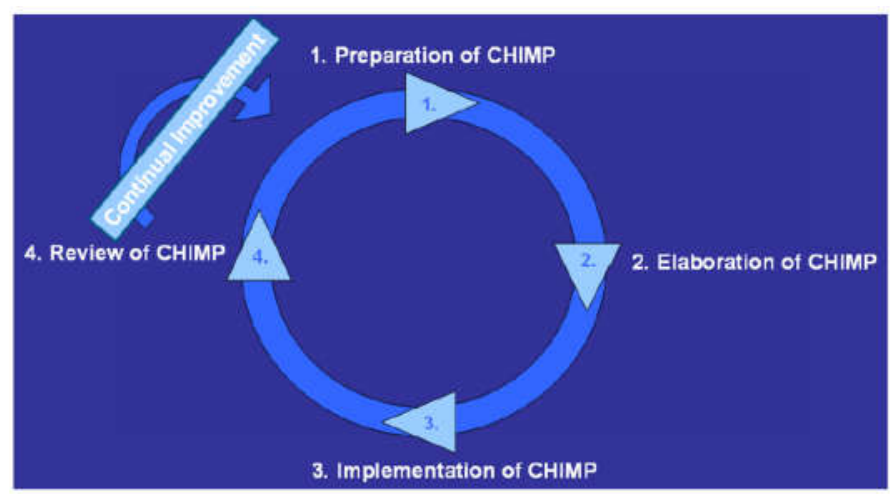

Gambar 3. "siklus hidup" dalam Pendekatan CHIMP (Sumber: Scheffler et al, 2009)

1. Preparation (persiapan)

Proses dalam siklus ini terdiri dari:

a) Melakukan analisis situasi kondisi existing (saat ini)

b) Mengembangkan tujuan, konten, dan struktur CHIMP

c) Menetapkan rencana kerja untuk penjabaran CHIMP

2. Elaboration (elaborasi)

Proses dalam siklus elaborasi terdiri dari

a) Menetapkan visi keseluruhan dan tujuan umum wilayah perkotaan yang mempunyai nilai sejarah

b) Menentukan bidang tindakan, sasaran dan strateginya (pendekatan terpadu)

c) Menetapkan tindakan yang mendukung tujuan 
3. Implementation (implementasi)

Merupakan siklus implementasi yaitu proses realisasi/pelaksanaan dari siklus pertama dan kedua

4. Review (review)

Review ini merupakan proses monitoring yang bertujuan untuk:

a) Mengamati dan menganalisis perkembangan, kemajuan, dan perubahan

b) Meninjau kinerja untuk mengendalikan kesuksesan dan memeriksa hasilnya

c) Memberikan informasi kepada masyarakat umum untuk meningkatkan kesadaran dan memberikan layanan konsultasi kepada warga, pemilik properti, dan investor tentang pengembangan kawasan kota bersejarah dan warisan budayanya.

d) Mendukung pengambilan keputusan yang objektif dan mengambil tindakan korektif

\section{PEMBAHASAN}

Dari penjelasan sebelumnya dapat diketahui bahwa, setidaknya ada dua hal pokok yang menjadi tujuan pelestarian warisan budaya perkotaan. Dua tujuan pokok tersebut yaitu:

1. Mampu menjaga nilai-nilai warisan budaya yang dimiliki sebagai kota yang khas dan unik dan menjadikan nilai serta warisan budaya yang dimiliki tersebut sebagai aset yang kuat untuk pengembangan dan pembangunan;

2. Pendekatan pengelolaan ini diharapkan mampu mengembangkan kota sebagai aset warisan yang multifungsi. Membuat bangunan-bangunan yang ada serta situs yang ada didalamnya sebagai tempat yang menarik untuk hidup, tinggal, beraktivitas dan menghidupkan ekonomi bagi semua pemangku kepentingan penduduk lokal, pengunjung dan pengusaha.

Dua tujuan pokok tersebut sesuai dengan apa yang dijelaskan dalam Hero"Heritage as Opportunity" melalui Gambar 4 bagan tujuan pelestarian warisan budaya perkotaan sebagai berikut:

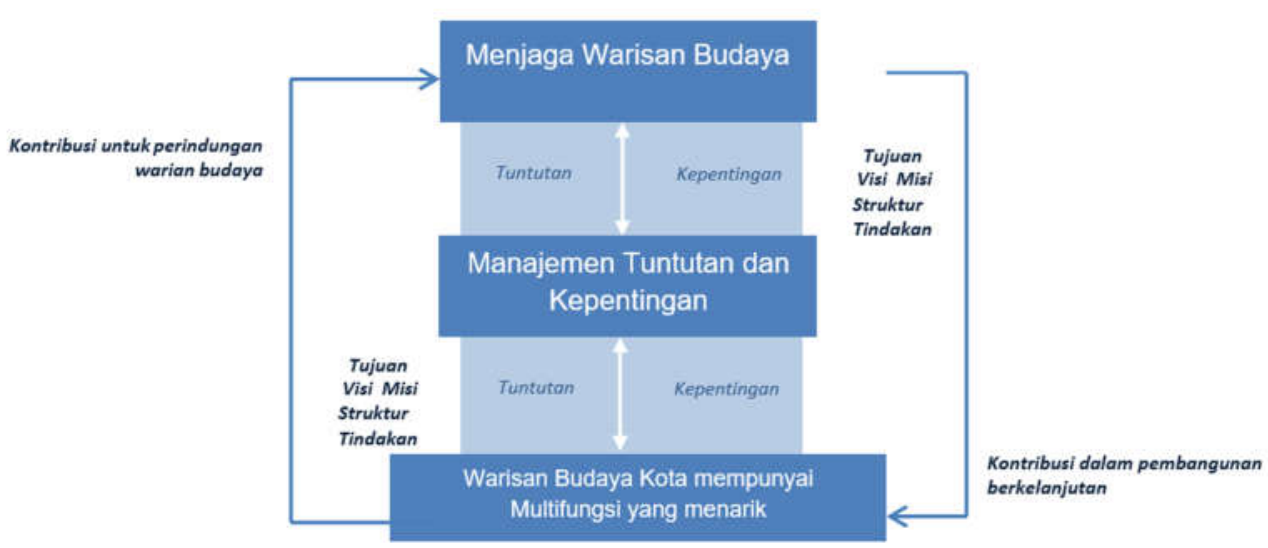

Gambar 4. Bagan tujuan dalam pendekatan pengelolaan warisan budaya

(Sumber: Hero "Heritage as Opportunity", 2011, guidebook yang sudah dimodifikasi) 
Penyelamatan (safeguarding) warisan budaya perkotaan (urban heritage) adalah tindak yang fundamental dalam pengelolaan aset untuk pembangunan dan memastikan kelangsungan warisan budaya dan identitas yang dimiliki oleh kota bersejarah tersebut (Rutkauskas dalam Integrated Management of Historic Towns Guidebook, 2011).

Sesuai dengan dua tujuan pokok di atas dapat dijelaskan bahwa pendekatan pelestarian warisan budaya perkotaan menggunakan metode HUL dan CHIMP sangat sesuai untuk dilaksanakan. Kedua pendekatan tersebut dilakukan melalui tahapan dan proses yang tidak terlepas dari nilai warisan budaya dan memperhatikan aspek ekonomi bagi semua pelaku perkotaan (stakeholder, penduduk lokal, pengunjung serta pengusaha). Hal yang membedakan antara kedua metode tersebut adalah prosentasi sasaran yang akan dicapai dalam pelestarian warisan budayanya. Pendekatan HUL lebih banyak bergerak diluar pelestarian fisik lingkungan, dan berfokus kepada lingkungan manusia beserta lingkungannya baik yang bersifat bendawi maupun tak bendawi. Untuk pendekatan CHIMP bergerak disemua aspek pelestarian baik fisik lingkungan dan juga non fisik. Dalam prosesnya, CHIMP bergerak melalui "siklus hidup" yang terdiri dari empat proses. Setiap pelaksanaan satu siklus selalu dilakukan evaluasi dan kemudian digunakan sebagai perbaikan untuk pelaksanaan pada rencana aksi selanjutnya.

Dari pengertian dan penjelasan pendekatan dengan HUL dan CHIMP tersebut lantas manakah yang lebih baik dilaksanakan? Baik pendekatan dengan HUL dan CHIMP merupakan dua pendekatan yang sebenarnya saling melengkapi. HUL tidak lantas lebih baik dari CHIMP, demikian pula sebaiknya. Penentuan metode yang akan digunakan harus terlebih dahulu melakukan identifikasi karakteristik kota bersejarah yang akan dilestarikan. Apakah karakteristik kota tersebut lebih didominasi oleh nilai budaya yang bersifat fisik atau sebaliknya kota tersebut lebih banyak nilai budaya non-fisiknya. Bagaimana sektor ekonomi yang berputar di kota tersebut dan seberapa besar tekanan pembangunan dan investor yang terjadi, kedua hal ini juga berpengaruh bagaimana kita menentukan metode pendekatan pelestarian yang akan digunakan.

Hal mendasar yang memberikan perbedaan antara kota modern dan kota bersejarah adalah bagaimana kota-kota tersebut dibentuk secara khusus dengan aset- aset budaya yang ada didalamnya. Aset-aset warisan budaya yang ada pada sebuah kota bersejarah seperti monumen, bangunan-bangunan, situs-situs, nilai-nilai tradisi sosial yang masih hidup dalam masyarakat tersebut. Baik pendekatan dengan HUL maupun CHIMP, ada tiga aspek pokok yang akan menerima manfaat secara spesifik, yaitu aspek ekonomi, sosial budaya dan lingkungan itu sendiri. Secara terperinci manfaat ketiga aspek tersebut dapat diuraikan sebagai berikut:

\section{Manfaat Ekonomi}

a) Melalui proses revitalisasi dalam usaha pelestarian warisan budaya perkotaan akan menciptakan lapangan kerja, melalui program padat karya dalam hal renovasi bangunan untuk pengembangan bisnis dan sektor ekonomi;

b) Dengan pelestarian melalui revitalisasi bangunan-bangunan bersejarah tersebut akan menyediakan tempat khusus untuk industri kreatif;

c) Hasil revitalisasi bangunan-bangunan sebagai tempat untuk menumbuhkan bisnis industri kreatif lokal dan industri budaya sebagai tempat untuk berinvestasi;

d) Dibandingkan kota lain, kota bersejarah mempunyai nilai keunikan tersendiri, image sebagai heritage town akan mampu menjadi branding tersendiri untuk menarik pengunjung dan masyarakat luas;

e) Investasi publik dalam hal warisan budaya mampu berfungsi sebagai katalis dalam proses revitalisasi yang lebih luas, menarik pihak lokal dan swasta external serta mampu merangsang tumbuhnya perkembangan baru.

\section{Manfaat Sosial dan Budaya}


a) Melalui proses revitalisasi dalam usaha pelestarian warisan budaya perkotaan akan berkontribusi dalam penyediaan tempat untuk kegiatan budaya dan kreatif;

b) Warisan budaya kota (urban heritage) dapat memberikan identitas lokal, kebanggaan dan menumbuhkan semangat masyarakatnya untuk tinggal dan bekerja mengembangkan ide dan kreativitasnya;

c) Warisan budaya kota (urban heritage) mampu memberikan ruang sebagai tempat untuk belajar tentang sejarah dan budaya;

d) Mampu menumbuhkan nilai-nilai patrimonial;

e) Dengan konsep pelestarian yang berdasar pada nilai kearifan lokal, maka setiap proses revitalisasi dan pengembangan kota akan lebih banyak melibatkan masyarakat sebagai satu bagian yang tidak terpisahkan dari nilai dan identitas yang dimiliki oleh kota bersejarah tersebut.

\section{Manfaat Lingkungan}

a) Dengan adanya revitalisasi bangunan lama yang ada dalam sebuah urban heritage secara otomatis akan mengurangi kebutuhan dan konsumsi material baru misalnya saja material untuk konstruksi;

b) Dengan memfungsikan kembali bangunan-bangunan lama yang menjadi bagian dari identitas kota bersejarah tersebut, maka kebutuhan ruang baik untuk bisnis ( industri kreatif, dan sebagainya) serta pemukiman sebagai tempat tinggal maka hal ini akan mengurangi kebutuhan akan lahan dan area publik;

c) Konsep pelestarian dari warisan budaya kota ini akan juga secara langsung akan melindungi konteks sejarah dalam ruang spasial yang dimiliki oleh kota tersebut. perlindungan pada area-area tersebut secara otomatis akan mengurangi jalur transportasi dan komuter masal yang secara dampak lingkungan akan memberikan kontribusi kepada polusi udara;

d) Perlindungan terhadap zona kawasan dalam kota bersejarah ini juga akan memberikan kontribusi terhadap mitigasi sub-urbaninasi.

Dalam usaha meningkatkan pelestarian warisan budaya perkotaan diseluruh dunia, UNESCO membentuk Jaringan Kota Kreatif (Unesco Crative City Network/UCCN) pada tahun 2004. Usaha membangun jaringan ini ditujukan untuk meningkatkan kerja sama diantara kota-kota yang telah mengidentifikasi kreativitas sebagai faktor strategis untuk pembangunan kota yang berkelanjutan. 180 kota yang masuk dalam jaringan ini bekerja bersama menuju tujuan bersama: menempatkan kreativitas dan industri budaya dalam prioritas rencana pembangunan di tingkat lokal dan bekerja sama secara aktif di tingkat internasional. Praktik dalam jaringan kota kreatif ini mengembangkan kemitraan dalam berbagai setor publik dan swasta serta masyarakat yang mempunyai tujuan untuk :

1. Memperkuat penciptaan, produksi, distribusi dan penyebaran kegiatan budaya, barang dan jasa;

2. Mengembangkan pusat kreativitas dan inovasi dan memperluas peluang bagi para pencipta dan profesional di sektor budaya;

3. Meningkatkan akses dan partisipasi dalam kehidupan budaya, khususnya bagi kelompok dan individu yang terpinggirkan atau rentan;

4. Sepenuhnya mengintegrasikan budaya dan kreativitas ke dalam rencana pembangunan berkelanjutan. 


\section{KESIMPULAN}

Dari kajian literatur tentang metode pendekatan dalam pelestarian warisan budaya perkotaan ini dapat diambil beberapa kesimpulan sebagai berikut :

1. Metode Heritage Urban Landscape (HUL) dan Cultural Heritage Integrated Management Plans (CHIMP) sesuai untuk diterapkan dalam pelestarian warisan budaya perkotaan. Tahapan melalui kedua metode pendekatan tersebut tidak terlepas dari aspek sosial-ekonomi, nilai dan identitas budaya yang dimiliki oleh kota yang akan dilestarikan. Dalam prosesnya kedua metode tersebut mampu menghubungkan dan menyeimbangkan antara pembangunan sosial-ekonomi yang berkelanjutan dengan perlindungan warisan budaya dan identitas yang dimiliki.

2. Perbedaan antara kedua metode tersebut adalah pada prosentasi sasaran yang akan dicapai dalam pelestarian warisan budayanya. Pendekatan HUL lebih banyak bergerak diluar pelestarian fisik lingkungan, dan berfokus kepada lingkungan manusia beserta lingkungannya baik yang bersifat bendawi maupun tak bendawi. Pendekatan CHIMP bergerak di semua aspek pelestarian baik fisik lingkungan dan juga non fisik.

3. Perbedaan kedua metode tersebut bukan merupakan kelebihan dan kekurangan sebuah metode. Baik pendekatan dengan HUL dan CHIMP merupakan dua pendekatan yang sebenarnya saling melengkapi. Setiap kota bersejarah memiliki karakteristik fisik dan non fisik yang berbeda-beda. Identifikasi karakteristik yang dimiliki ini menjadi penentuan awal apakah metode pendekatan dengan HUL atau CHIMP. Karakteristik kota dengan karakteristik dan nilai budaya yang bersifat fisik lebih cocok menggunakan pendekatan CHIMP dan sebaliknya kota yang mempunyai lebih banyak karakter nilai budaya non fisik akan lebih sesuai menggunakan pendekatan HUL. Bagaimana sektor ekonomi yang berputar di kota tersebut dan seberapa besar tekanan pembangunan dan investor yang terjadi, kedua hal ini juga berpengaruh bagaimana kita menentukan metode pendekatan pelestarian yang akan digunakan. 


\section{DAFTAR PUSTAKA}

Banderin, F. dan R. van Oers. The Historic Urban Landscape: Managing Heritage in an Urban Century. West Sussex: Viley-Blackwell, 2012.

Negussie, Elene dan Kerstin Westerlund Bjurström. Using Hul To Introduce A New Heritage Driven Concept For City Development: The Stockholm experience. ICOMOS, 2014.

Regensburg, Stadt. Hero "Heritage as Opportunity": "The Roads to Succes", Integrated Management of Historic Town. Guidebook. Germany, 2011.

Scheffler, Nils, Matthias Ripp, Barbara Bühler dan HerO Lead Partner. HerO "Heritage as Opprtunity". "The Roads to Success: Integrated Management of Historic Town, Thematic Report (4). 2010.

Scheffler, Nils in cooperation with Matthias Ripp and Barbara Bühler. Cultural Heritage Integrated Management Plans. Thematic Report (1.0). 2009.

UNESCO World Heritage Centre. Vienna Memorandum on World Heritage and Contemporary Architecture Managing the Historic Urban Landscape, 20 May 2005. Vienna, Austria: UNESCO World Heritage Centre, 2005.

UNESCO. Recommendation on the Historic Urban Landscape. Paris: UNESCO, 2011.

UNESCO. The Hul Guidebook : Managing heritage in dynamic and constantly changing urban environments. A practical guide to UNESCO recommendation on the Historic Urban Landscape. 2016. 